\title{
直腸脱に対する経肛門的手術の治療效果
}

\author{
弘前市東北肛門病院 \\ 鳴海裕行見滝伸忠遠藤尚孝
}

経肚門的手術による直腸脱の治潦効果について検討を加えた。

1）術式注直腸の粘膜結禁術と肛門輪の縮小術とを同時に施行する方法である.

2) 最近 6 年間の症例は 32 例で, 男女比は 16 対 16 , 年齢は最低 5 歳, 最高が78歳であった.

3）術後満 1 年以上を経過した27例の遠隔成績をみると, 消息の判明した24例のうち19例に 良好な結果を 得ることができた.

4）以上の成績から本法は高龄者や年少者に推奖すべき方法であることを強調するとともに，開腹して固 定術を施行するに先立ちまず最初に試みるべきことを強調するものである.

\section{I. まえおき}

直腸脱の手術的療法としては徒来より多数の力法がと られ，極めて煩雑であるばかりでなく，その術式の選択 《は我々臨床医の迷らところでも㐫る。これらの多くの 術式を整理してみると表 1 の如くで，さらに大別すると

表 1 亩晹脱の治療

\section{I . 姑息的療法 \\ II. 注射療法 \\ III. 手術的療法}

1）肛門括約部の縮小, 補強を図る方法・経肛阴的

2) 直腸縫合，縫縮術…………経肛門的

3）直腸切除術……....経会陰的, 経腹腔的

4）骨盤底を補強する方法………释腹胵的

5）結腸，直腸の固定術…経仙骨的，释腹腔的

淫肚門的ないしは経会陰的方法と開腹して経腹腔的に行 なう方法とに分けられると思ら。経肛門的手術としては 古くから Thiersch 氏法が知られているが，その效果は 不確実とされ，さらに以前には最も多く行なわれた直腸 のの切除術もその再発率が高いことと相俟って最近では等 ら直腸固定術が施行されている現況のようである.しか しながら直腸固定術は年少者や高齢者にとっては侵襲が 大きく，特に自然治癌を期待出来る小览に実施すること は無理である.

一方経肛門的に肛門括約部の狭小や強化を図る方法は それのみでは效果が薄く, 現在では直腸固定術に附加し て行なわれている状態である。乙かしながらその手技が 一簡単でしかも侵襲の少ないことでは極めて理想的な手術 ということができる，我々はこの点に注目し，経肛門的 にていわる Thiersch 氏法に加えて直腸粘膜の結禁術を
併用する方法を徒来より試みているが，その成績につい て一応の結果を得たので報告する次第である.

\section{II. 術式}

麻酔, 消毒をした後,まず第一に直腸粘膜の結紮術を 行なう。直腸腔を十分拉げ, 図 1, 図 2 の如く歯状線上 り約 $1 \mathrm{~cm}$ 上方の $3^{\mathrm{h}}, 6^{\mathrm{h}}, 9^{\mathrm{h}}, 12^{\mathrm{h}} の 4$ 力の粘膜を示指

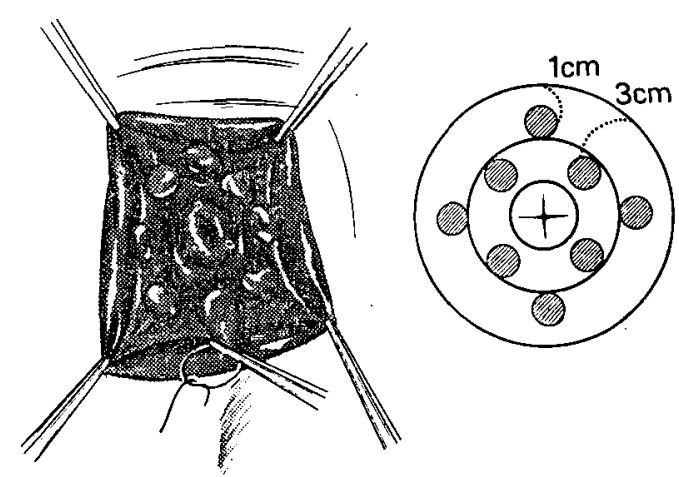

図 1 粘膜結禁桬

頭大にペアン氏鉗子にて把持しこれを結柴する. さらに 上方 $3 \mathrm{~cm}$ 位の部の粘膜を先に結禁した個所の中間四力 所にて同様の結樂を行う.結紮の部位は必ずしも上記の 所でなくてもいいし，また脱出粘膜が高度である場合に は結紫の大きさが自然に大きくなり，結禁の部位もさら に上方へ及ぶこともある. 結禁した粘膜は切除してもし なくてもよいが，粘膜をちぎって出血させないように十 分注意する.この方法の目的は粘膜を結紫することによ って洀浪をうくることと，直腸腔の狭小化を図ることに あり，それによって直腸粘膜の脱出，棌転を防ぐことに 


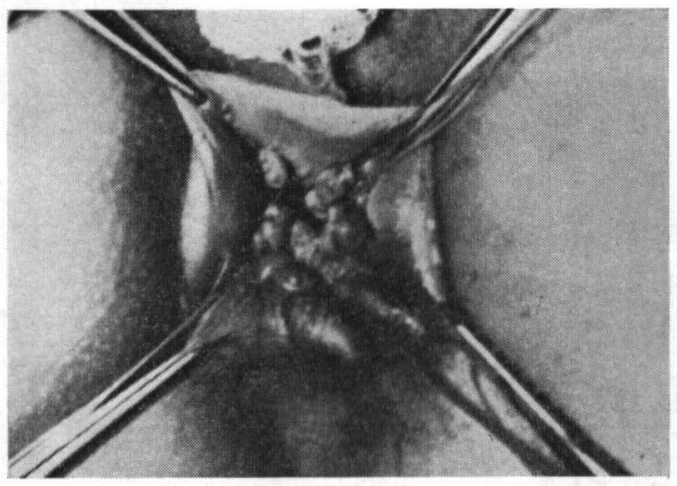

図 2 粘膜結禁術 (術中写真)

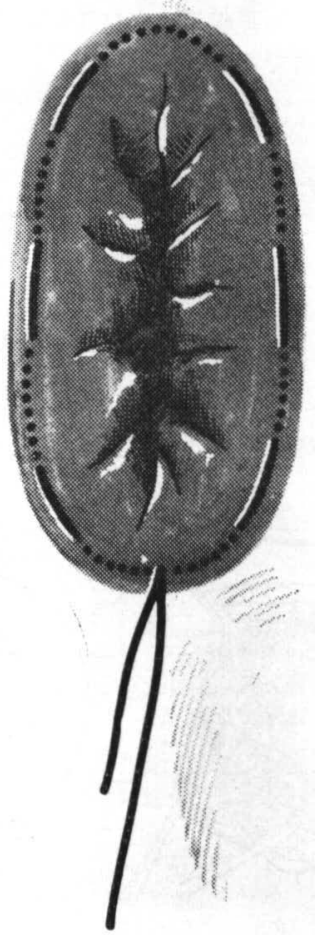

図 3 肛門輪縮小術

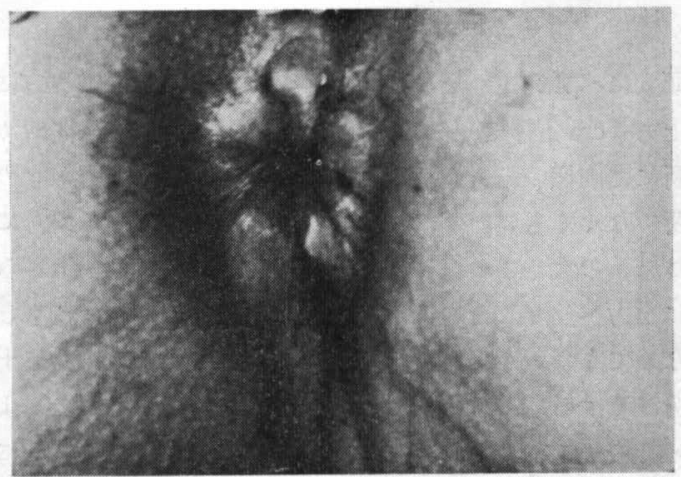

図 4 肚門輪縮小術（術中写真）
表 2 症例

\begin{tabular}{|c|c|c|c|c|c|c|c|c|c|c|}
\hline 例 & 性 & 㱓 & $\begin{array}{l}\text { 病 } \\
\text { 絔 } \\
\text { 期 } \\
\text { 間 }\end{array}$ & 大きさ & $\begin{array}{l}\text { 失 } \\
\text { 禁 }\end{array}$ & $\begin{array}{l}\text { 精 } \\
\text { 神 } \\
\text { 障 } \\
\text { 害 }\end{array}$ & $\begin{array}{l}\text { 合 } \\
\text { 併 } \\
\text { 症 }\end{array}$ & $\begin{array}{l}\text { 再 } \\
\text { 手 } \\
\text { 術 }\end{array}$ & $\begin{array}{r}\text { 術経 } \\
\text { 過 } \\
\text { 年 } \\
\text { 後月 }\end{array}$ & $\begin{array}{l}\text { 術 } \\
\text { 後 } \\
\text { 成 } \\
\text { 績 }\end{array}$ \\
\hline 1 & 우 & $\begin{array}{l}\text { 歳 } \\
78\end{array}$ & $\begin{array}{c}\text { 年 } \\
20\end{array}$ & 手拳大 & $(+)$ & & & & $\begin{array}{cc}\text { 年 } & \text { 月 } \\
6 . & 10\end{array}$ & \\
\hline 2 & 우 & 25 & 15 & 小児頭大 & $(+)$ & $(+)$ & & & 6. 5 & 治: \\
\hline 3 & 今 & 41 & 10 & 鶏卵大 & $(+)$ & $(+)$ & & & 6. & 治: \\
\hline 4 & $\hat{\sigma}$ & 18 & 不明. & 手拳大 & $(+)$ & $(+)$ & & & 5. & 治: \\
\hline 5 & 今 & 30 & 15 & 小児頭大 & $(+)$ & & $\begin{array}{l}\text { 後出 } \\
\text { 血 }\end{array}$ & & 5. 8 & \\
\hline 6 & 우 & 53 & 40 & 手拳大 & $(+)$ & & & & 4. 8 & \\
\hline 7 & $\hat{0}$ & 25 & 6 & 小児頭大 & $(+)$ & $(+)$ & & & 4. & \\
\hline 8 & 우 & 22 & 1 & 手丵大 & & $(+)$ & & & 4. & \\
\hline 9 & $\hat{0}$ & 30 & 15 & 手㚐大 & & & & $\begin{array}{l}\text { 再手: } \\
\text { 術 }\end{array}$ & 3. & \\
\hline 10 & $\hat{0}$ & 5 & 3 & 䊿卵大 & & & & & 3. & \\
\hline 11 & $\hat{o}$ & 64 & 6 & 鶏卵大 & & & & & 3. & \\
\hline 12 & 우 & 57 & 2 & 手掱大 & & & & & 3. & \\
\hline 13 & 우 & 43 & 2 & 鶏卵大 & & & & & 3. & \\
\hline 14 & 우 & 60 & 20 & 手拳大 & $(+)$ & & & & 3. & 再: \\
\hline 15 & $\hat{0}$ & 73 & 30 & 手拳大 & $(+)$ & & & & 3. & \\
\hline 16 & $\hat{0}$ & 71 & 20 & 手拳大 & & & & & 2. & \\
\hline 17 & $\hat{0}$ & 31 & 15 & 手拳大 & & & & $\begin{array}{c}\text { 再手 } \\
\text { 術 }\end{array}$ & 2. & \\
\hline 18 & 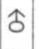 & 16 & 10 & 鶏卵大 & & & & & 2. 9 & 再: \\
\hline 19 & 우 & 22 & 5 & 手拳大 & $(+)$ & & & & 2. 5 & 治米 \\
\hline 20 & $\hat{\sigma}$ & 5 & 2 & 鶏卵大 & & & & & 2. 4 & 不 \\
\hline 21 & 우 & 66 & 30 & 小児頭大 & & $(+)$ & & $\begin{array}{l}\text { 再手 } \\
\text { 術 }\end{array}$ & 2. & \\
\hline 22 & 우 & 36 & 10 & 手拳大 & $(+)$ & & & & 2. 2 & 治为 \\
\hline 23 & 우 & 60 & 20 & 手拳大 & $(+)$ & & & & 1. 11 & 治㾙 \\
\hline 24 & $\hat{0}$ & 19 & 7 & 小児頭大 & $(+)$ & $(+)$ & & & 1. 10 & 再発 \\
\hline 25 & 우 & 72 & 2 & 手拳大 & & & & & 1. 10 & 再発 \\
\hline 26 & $\hat{\delta}$ & 40 & 3 & 手拳太 & & & 化膿 & & 1. 6 & 再発 \\
\hline 27 & 令 & 76 & 40 & 小児頭大 & $(+)$ & & & & 1. 6 & 治瘜 \\
\hline 28 & $\hat{\sigma}$ & 40 & 3 & 小児頭大 & $(+)$ & $(+)$ & & & 1. & - \\
\hline 29 & 우 & 28 & 20 & 手拳大 & & & & & 1. & 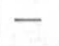 \\
\hline 30 & 우 & 25 & 1 & 鶏卵大 & & & & & 1. & 一 \\
\hline 1 & 우 & 65 & 25 & 鶏卵大 & & & & & 1. 0 & 一 \\
\hline & 우 & 70 & $20=$ & 手拳大 & & & & & 1. & \\
\hline
\end{tabular}

ある.

次に直径 1 $2 \mathrm{~mm}$ のナイロン采を用い Thiersch 氏: 法に準じ肛門輪の縮小術を行な5.すなわち図 3 , 図 4 の如く肚門下縁より上方に巾着縫合の要領で系を通し示: 指を通じる程度に締めておく. ナイロン糸は多少伸縮す るため銀線に比較して術後の排便に好都合であり，また 断端部の局所に対する刺载も少ないようである。この方 法の目的とするところは肛門輪部に 瘢痕をつくること と，脱出を防いでいる間に驰緩した直腸の周囲組織や肛 


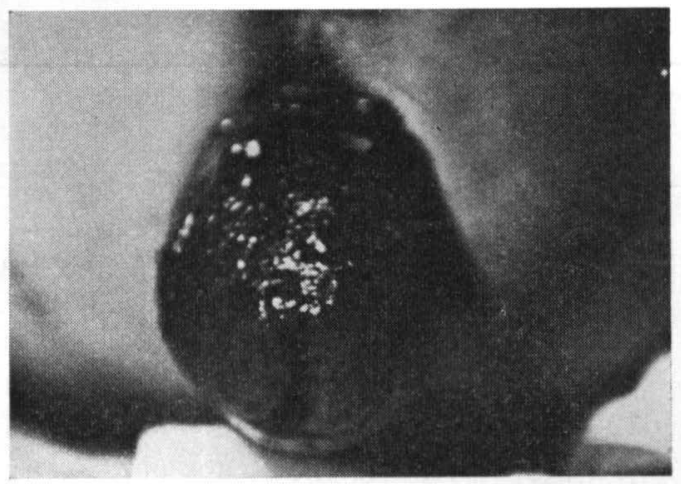

図 5 症例 脱出時のもの

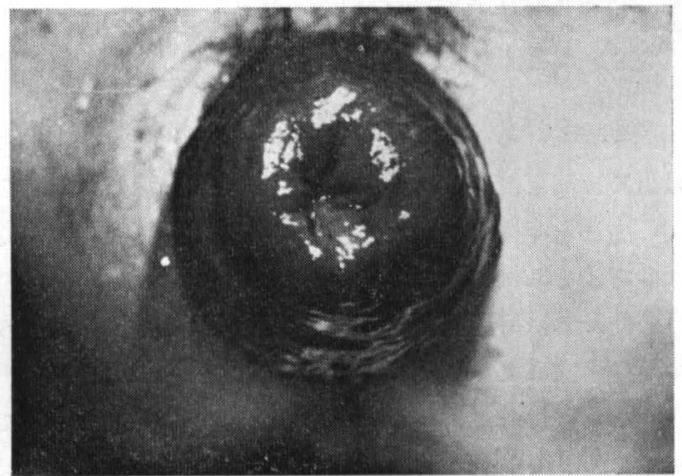

図 6 症例 脱出時のもの

門括約筋の回復, 強化を図ることにある. 従ってナイロ ン系は術後に化膿がみられず, 患者の苦痛がなければな るべく長期間に亘って放置しておく．

\section{III. 症 例}

昭和 40 年以降昭和 45 年末までの 6 年間に本法を旋行し た症例は32例で, その内訳については表 2 に示してあ る. 男女比をみると男性 16 人に対し女性 16 人と同率にな っており, 最高年龄は78歳, 最低年齢が 5 歳で, 平均年 齡は 42 歳 6 力月となっている. 60 歳以上の高龄者は 11 人 となっており, 全体の約 $1 / 3$ を占めているのが注目され る. 病悩期間の平均は 13 年 4 力月であり, また脱出の大 きさは小児頭大が 7 例, 手拳大 17 例, 鶏卵大 8 例となっ ている. 図 5 , 図 6 は夫々症例 7 , 症例 27 脱出時の写 真である。

\section{IV. 手術成 績}

術後合併症としてはナイロン采挿入部の化膿が 1 例, 結禁部位からの後出血が 1 例にみられた. また症例 9 ， 症例 17 , 症例 $21 の 3$ 例は術後 2,3 力月の比較的早期に ナイロン糸を除去したためか再脱出が認められたが, 直 腸粘膜の結紮術と肛門輪の縮小術を最初からやり直し治
癒している. すなわち本法の施行は 2 回, 3 回とくり返 すことが可能である.

さて術後成績であるが，昭和 44 年末までに手術を受け 少くとも満 1 年以上を経過した 27 症例についてその効果 をみると, 表 2 に示されているような結果が得られた. すなわち消息の明確なもの 24 例（消息判明率 $88.9 \%$ ）の らち, 再脱出が全く認められないものは19例であり, 再 脱出を来たし再発とみられたものが 5 例であった. すな わち $79.2 \%$ には良好な結果を認めることが出来た.

\section{V. 考 察}

当院における直腸脱の頻度をみると, 表 3 に示してあ る如く 6 年間の全手術総数 5501 例のうちの32例で $0.56 \%$ に相当している. これは表 4 の小平 ${ }^{1)}$, 渡辺 ${ }^{2}$, 脇坂 ${ }^{3)}$, 隅越4らの報告とほぼ同様の発生頻度となっており, 本 疾患は我々臨床医のしばしば遭遇するものの一つといら ことが出来る. 特に Palmer ${ }^{5)}$ の指摘している如く, 比 較的若年者の群と高年者の 2 群に好発することは我々の 経験からも知ることが出来た.

さてその手術術式についてであるがが，Gabriel'卢の記 載によると Thiersch が1891年に始めて発表したとされ

表 3 手術症例

（昭和 $40 \sim 45$ 年）

\begin{tabular}{|c|c|c|}
\hline & & 例 数 \\
\hline 外 & 痚 & 269 \\
\hline 内 疛 & 核, 脱 肘 & 3542 \\
\hline 痔 瘻, & 肛 直 膿 & 1140 \\
\hline 裂 & 肛 & 205 \\
\hline 乳 & 頭 & 159 \\
\hline 直 & 腸 & 32 \\
\hline 狭 & 窄 & 42 \\
\hline 瘙 & 痒症 & 67 \\
\hline 癌, ポ & リープ他 & 45 \\
\hline & 計 & 5501 \\
\hline
\end{tabular}

ている肚門輪縮小術は初期の頃盛んに行なわれていたよ らであるが，次第に効果のないものと考えられるよ になり, Rehn-Delorme に代表される脱出腸管の切除術 がその術式の主流を占めるようになった. しかしながら この切除術も Bacon ${ }^{7}$, Pemberton ${ }^{8}$, 高山帛らの報告に みられる如く再発率が極めて高く, 現在では経腹腔的に 腸管を拳上しこれを固定する方法が一番安全で確実な方 法とされるに至った. 以上の術式の推移については，我 国における昭和 33 年の小平 ${ }^{11}$ の調查と昭和 45 年における 隅越4)の調查とを比較してみると数字的に明らかであ る. 
表 4 直腸脱の頸度

\begin{tabular}{|c|c|c|c|c|c|c|c|c|c|c|c|c|}
\hline & & & \multicolumn{2}{|l|}{ 小 } & \multicolumn{2}{|l|}{ 渡 } & \multicolumn{2}{|l|}{ 脇 } & 隅 & 越 & 著 & 者 \\
\hline & & & 例 数 & $\%$ & 例 数 & $\%$ & 例 数 & $\%$ & 例 数 & $\%$ & 例 数 & $\%$ \\
\hline 外 & 痔 & 核 & 2391 & 19.8 & & & 12415 & 20.7 & 17631 & 66.5 & 269 & 4.9 \\
\hline 内 & 痔 & 核 & 5304 & 43.8 & 3666 & 76.7 & 26266 & 43.8 & 3584 & 13.5 & 3542 & 64.5 \\
\hline 樭, & 肛 直 & 膿 & 2810 & 23.2 & 654 & 13.7 & 11919 & 19.9 & 2993 & 11.3 & 1140 & 20.7 \\
\hline 裂 & & 肛 & 866 & 7.2 & 236 & 4.9 & 7714 & 12.9 & 101 & 0.4 & 205 & 3.6 \\
\hline 直 & 腸 & 脱 & 253 & 2.1 & 22 & 0.5 & 367 & 0.6 & 55 & 0.2 & 32 & 0.6 \\
\hline 狭 & 窄 & 症 & 102 & 0.8 & 7 & 0.2 & 184 & 0.3 & & & 42 & 0.8 \\
\hline 瘙 & 痒 & 症 & & & 68 & 1.4 & & & & & 67 & 1.2 \\
\hline 乳 & 頭 & 炎 & & & & & & & 425 & 1.6 & 159 & 2.9 \\
\hline 癌, ポ & 1) $->$ & 他 & 269 & 2.2 & 126 & 2.5 & 1063 & 1.8 & 1711 & 6.5 & 45 & 0.8 \\
\hline & 計 & & 12095 & 100 & 4779 & 100 & 59928 & 100 & 26500 & 100 & 5501. & 100 \\
\hline
\end{tabular}

しかしながら直腸の固定術はややもすると手術侵襲が 大きくなり, 高龄者や年少者には極めて危険度の高、手 術であることは我々臨床医のよく識るところである。ま た固定術そのものについても人によってかなりの再発率 が報告9)されており，簡単に直腸脱の手術即固定術之い う考えには領けないものがある.我々はこのような固定 術一辺倒の考えに対し，経肚門的に簡単でしかも侵襲の 少ない方法を施行する立場をとって抢り，しかもかなり の効果を期待し得ることを以前から確信していたのであ る.

術式はすでに述べた如く，直腸の粘膜結森術と肛門輪 の縮小術と同時に施行する方法である、粘膜の結禁術は 三輪103によれば Gant 氏法とよばれているものに相当 し，また古くから絞り染め結紮法として坂口11が行なっ ていた方法にも準じたものであるう。いずれにしてもそ の意図するところは直腸腔の狭小化と洀痕を形成せしめ ることにあって，それにより腸管の脱出觮転を阻止する ことにある.ただそれのみでは不十分であるため肛門輪 の縮小術を附加する訳である，一般に直腸脱の患者は肛 門括約筋の発育が瑟く，しかも頻繁なる脱出のため括約 筋は弛緩疲幣してしまっている. 従って便失禁のみられ るのが普通で事実自験例32例の5ち15例と約半数に失禁 が認められている。このようなものに肛門輪の縮小術を 行なって脱出を阻止し，その間に括約筋の回復強化を図 ること注極めて理屈に合ったものと云えよう. Thiersch の原法注銀線を使用しているが，我々はナイロン糸を使 用し好結果を得ている.ナイロン系を使用した方法とし

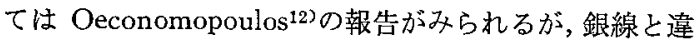
って多少伸縮するため排便に好都合で，異物感や疼痛も 軽く，また挿入部の損傷による糸の離脱の頻度も少ない ように思われる. 以上の方法は 2 回, 3 回とくり返しそ
の効果をあげることも可能で，非常に便利である．また 最近では明管液を肛門周囲に注入乙，周囲組織の硬化を 図る方法を手術時化併用し検討を加えている，我々は以 上の方法を32例に施行し, 術後 1 年以上経過した 27 例の うち約 $80 \%$ に好結果を得ることが出来た。これは過去の 種々の術式に上る多数の報告,例えば最近の Malyshev ${ }^{13}$ の9020例の統計と比較してもかなり良好な成績と云って いいものであろう，侵襲の少ないことから考えても，い きなり開腹をするよりもまず試みるべき方法であること を強調するものである、

ただこの方法の非適応としては, Buie ${ }^{14)}$ 分類による Concealed type のもの, 寸なわち直腸上部から值腸腔 内へ Invagination の形で脱出してくるものがあげら れ，これはいかに直腸下部に操作を加えても效果のない ことは明らかであろう、またあまりに肛門括約筋の発育 の恶いものについてもその效果は期待し得ないものと考 える.ただ肛門括約筋のトーヌス測定やその臨床的意義 については僅かに今井152などの報告をみるのみでいまだ に確立されたものがなく，我々が先に手がけた筋電図学 的方法 ${ }^{16)}$ とかその他今後にまつべきものがあると云えよ う.また S 字状結腸過長症を含め内臓下垂症を併発して いるものに対して腹成術を施行し, 直腸肍門部に直接ま たは閒接的に働く腹圧及び重力を軽減してやる必要があ ると説く槙ら 17)18)19〉の報告注注目すべきものである。術 前における慎重な腸管のレ線学的検討は当然必要である う、いずれにしてもこれらのものは本法の適応外とすべ きで，始めから固定術の適応とされるものと洘える. 自 験例のうちで再発を来たした 5 例中 2 例は, その後の検 菜でいわ化る Concealed type に属する症例であった。

最後につ汀加えると, 自験32例の5ち8例に精神薄弱 をはじめ精神分裂症などの患者が含まれており，Gre- 
gory, Jr. ${ }^{20)}$, Goligher ${ }^{21} ら か ゙$ 指摘している如く精神病患 者の率が極めて高くなっている，病歴をとって気がつく ことであるが，これらの患者は排便時間が警くほぼ長 く，2，3時閒に及ぶもの法ざらである，発生原因とし て先天的な因子の他に, 後天的なものとして排便時閒が 極端に長く，しかも排便終了後さらに必要以上に怒責市 る習慣は本症発生の重要な因子であることを指摘するも のである.

\section{VI. まとめ}

経肚閒的手術による直腸脱の治療効果について検討を 加えた.

1）術式位直腸の粘膜結紮術と肛門輪の縮小術とを同 特に施行する方法である。

2) 最近 6 年間の症例注32例で，男女比は 16 対16, 年 齢は最低 5 歳, 最高78歳であった。

3）術後満 1 年以上を経過した27例の遗隔成績をみる と，消息の判明した24例のうち19例に良好な結果を得る ことが出来た。

4）以上の成績から, 本法は高齡者や年少者に推奖す ベき方法であることを強調するとともに，開腹して固定 術を施行するに先立ちまず最初にに試みるぶきことを強 調するものである。

\section{参考文献}

1) 小平 正：直腸肛門誌， $\mathbf{1 5}(1) ， 1$, 昭33.

2) 渡辺元治：大腸肚門誌: 20(1)，1，昭40.

3）脇坟順一他：手術，21，464，昭42.

4）隅越幸男他：大腸肛門誌，23(1)，36，昭45.

5) Palmer, J. A. : SGO, 112, 502, 1961.

6) Gabriel, W. B. : The Principles and Practice of Rectal Surgery, 5ed., H. K. Lewis Co., 1963.

7) Bacon, H. E. : The Anus, Rectum and Sigmoid, 3 ed., J. B. Lippincott Co., 1949.

8) Pemberton, A. H. et al.: Ann. Surg., 109, $799,1953$.

9）高山坦三他：外会㟝療， 2, 1630 , 昭35.

10) 三輪徳定：肚門病の治療, 南山堂, 昭37.

11）坂口 勇：直腸肛門誌， 11(2)，9，昭 29 .

12) Oeconomopoulos, C. T. et al.: Amer. J. Surg., 100, 457, 1960.

13) Malyshev, Ju. I. : Am. J. Proctol., 22, 255, 1971.

14) Buie, L. A. : Practical Proctology, W. B. Saunders Co., 1937.

15）今井五郎他：大腸肛門誌，20(3)，182, 昭42.

16) 杉沢利雄他：大腸肛門誌，24(1)，10, 炤46.

17) 槙 哲大他：大腸肛門誌， $20(2) ， 77$, 炤41.

18）槙 哲夫：手術，11，1，昭 32 .

19）黑田 俊他：手術, 18, 354, 昭39.

20) Gregory, Jr., E. J. : Ann. Surg., 155, 495, 1962.

21) Goligher, J. C.: Surgery of the Anus, Rectum and Colon, 2 ed., Bailliere, Tindall \& Cassell, 1967. 
1)
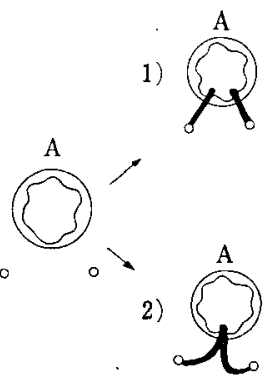
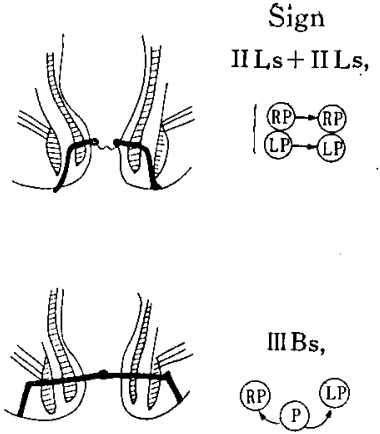

The following example is a complicated fistula which spreads into bilateral ischiorectal spaces and also into high intermuscular space with the form of horse-shoe. It has a secondary opening only in left posterior perianal region.

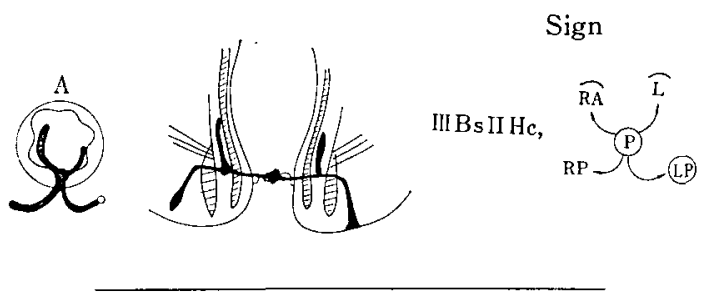

\section{The Operative Results of Anal Approach for Prolapsus Ani}

H. Narumi, M.D., N. Mitaki, M.D. and N. Endo, M.D.

Tohoku Proctologic Clinic, Hirosaki

The results after the operation of anal approach for prolapsus ani were described.

1) The operative procedure employed were ligature of the rectal mucosa and simultaneous narrowing of the anal ring.

2) Thirty-two cases in recent 6 years were investigated. Half of the cases were male. The youngest patient was 5 of age, the oldest patient was 78 of age.

3) Twenty-seven cases were followed up for one year after the operation. Nineteen cases out of 24 cases, that could be completely followed up, showed good results.

4) It could be emphasized that this operative method is able to apply to younger or older patients because of its good result. This operative procedure must be considered first before abdominal operation is performed. 